\title{
Myocardial Response to Acute Injury
}




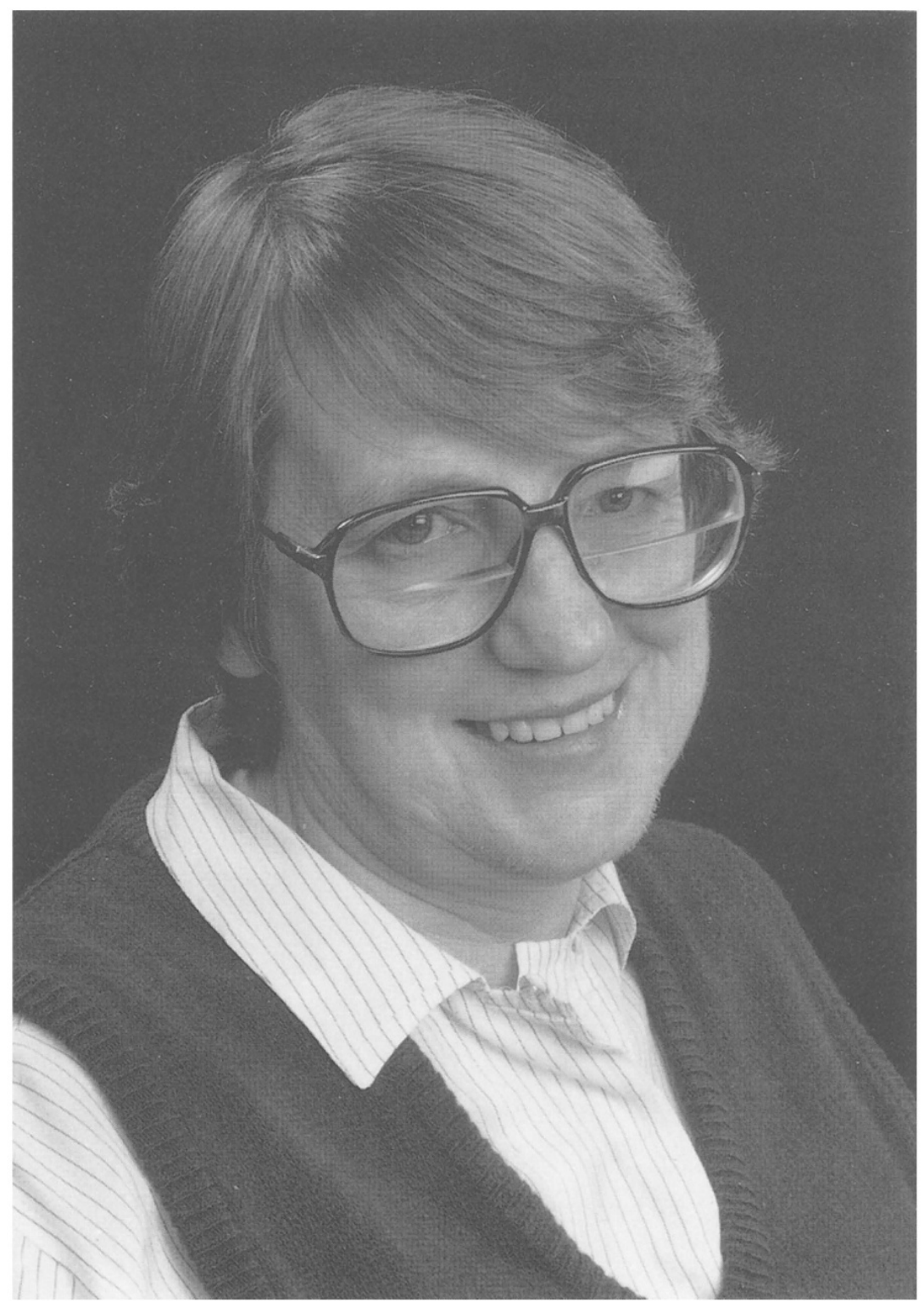

Professor Winifred Nayler 


\title{
Myocardial Response to Acute Injury
}

\author{
Edited by \\ JAMES R. PARRATT \\ Professor of Cardiovascular Pharmacology \\ University of Strathclyde, Glasgow, UK
}

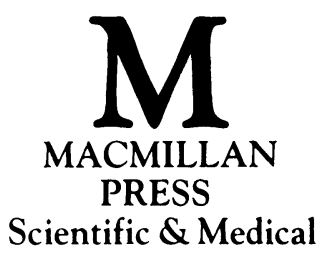


(C) The Macmillan Press Ltd 1992

Softcover reprint of the hardcover 1st edition 1992 978-0-333-55712-9

All rights reserved. No reproduction, copy or transmission of this publication may be made without written permission.

No paragraph of this publication may be reproduced, copied or transmitted save with written permission or in accordance with the provisions of the Copyright, Designs and Patents Act 1988, or under the terms of any licence permitting limited copying issued by the Copyright Licensing Agency, 90 Tottenham Court Road, London W1P 9HE.

Any person who does any unauthorized act in relation to this publication may be liable to criminal prosecution and civil claims for damages.

First published 1992 by

MACMILLAN ACADEMIC AND PROFESSIONAL LTD

Houndmills, Basingstoke, Hampshire RG21 2XS

and London

Companies and representatives

throughout the world

ISBN 978-1-349-12524-1

ISBN 978-1-349-12522-7 (eBook)

DOI $10.1007 / 978-1-349-12522-7$

A catalogue record for this book is available

from the British Library.

Filmset by Wearside Tradespools, Fulwell, Sunderland 


\section{Contents}

Frontispiece. Professor Winifred Nayler ii

The Contributors ix

Winifred Nayler: A Tribute xii

Preface xiii

1 Myocardial injury and repair J. Schaper, S. Hein, 1

C. M. Heinrichs and D. Weihrauch

Introduction 1

Acute ischaemic injury 1

Reperfusion of the ischaemic myocardium 4

Role of blood cells $\quad 8$

Summary 13

2 Lethal reperfusion injury: fact or fancy? $R$. B. Jennings and 17 K. A. Reimer

Introduction $\quad 17$

Effects of reperfusion with arterial blood on ischaemic tissue $\quad 21$

$\begin{array}{ll}\text { Lethal reperfusion injury } & 29\end{array}$

Conclusions and Summary 31

3 Morphological changes following acute ischaemia: fact or 35 fiction? G. Bullock

Introduction $\quad 35$

Ischaemic events $\quad 36$

Regional changes $\quad 37$

Specimen handling $\quad 38$

Summary $\quad 46$

4 Calcium ions and ventricular arrhythmias $\quad$ L. H. Opie, 48 W. A. Coetzee and W. T. Clusin

Introduction $\quad 48$

Calcium ions and ventricular arrhythmias during early $\quad 49$ ischaemia 
Role of calcium ions during reperfusion arrhythmias $\quad 58$

Evaluation of the therapeutic role of calcium antagonists in $\quad 61$

ventricular arrhythmias of ischaemic heart disease

Conclusion

5 Calcium fluxes and reperfusion damage: the role of

mitochondria D. Stone, V. Darley-Usmar and J. F. Martin

Introduction

Central role of oxygen in $\mathrm{Ca}^{2+}$ overload

Route of $\mathrm{Ca}^{2+}$ uptake and sequestration on reoxygenation

$\mathrm{Ca}^{2+}$ homoeostasis during hypoxia

$\mathrm{Ca}^{2+}$ uptake on reoxygenation

Effects of hypoxia/reoxygenation on mitochondrial function

Relationship of $\mathrm{Ca}^{2+}$ uptake to cell lysis and reperfusion damage

Summary

6 Ion movements early in myocardial ischaemia: relation to arrhythmias, early contractile failure and tissue necrosis P. A. Poole-Wilson

Introduction

Myocardial ischaemia

$\begin{array}{ll}\text { Early ionic events-potassium } & 84\end{array}$

Early ionic events-acidosis $\quad 88$

Early ionic events—calcium, magnesium, sodium $\quad 89$

Relation of ion movements to the action potential and $\quad 90$ contractility

Late ionic events and the relation to cell necrosis

7 The current of injury in acute myocardial ischaemia $M . J$.

Janse and R. Coronel

Introduction

Changes in intra- and extracellular potentials caused by ischaemia

Diastolic current of injury

Possible arrhythmogenic role of the injury current 103

Conclusion

8 Preconditioning: an early protective response to myocardial ischaemia A. Vegh, L. Szekeres and J. R. Parratt

Introduction

Mechanisms of the protective effect of preconditioning 
Prostanoids as endogenous protective substances $\quad 120$

Other protective, non-prostanoid substances 122

9 Platelet-derived substances in acute myocardial injury 128

C. L. Wainwright and J. R. Parratt

$\begin{array}{ll}\text { Introduction } & 128\end{array}$

Evidence for platelet activation and release of platelet-derived $\quad 128$ substances during myocardial ischaemia

Evidence that thromboxane and PAF induce myocardial 131 damage

Pharmacological inhibition of the actions of platelet-derived 132 substances: effects on myocardial injury

Conclusions

10 Interactions between neutrophils and coronary

microvessels F. M. Williams and T. J. Williams

Introduction

Myocardial infarction and acute inflammation 142

Myocardial infarction and the neutrophil 142

Myocardial infarction and the complement system 145

Leukotriene $B_{4}$ and other neutrophil chemoattractants $\quad 146$

$\begin{array}{ll}\text { Adhesion glycoproteins } & 147\end{array}$

$\begin{array}{lr}\text { Vascular permeability } & 148\end{array}$

$\begin{array}{ll}\text { Conclusion } & 150\end{array}$

11 Effects of endocardial damage on myocardial contraction 153 A. M. Shah and A. H. Henderson

$\begin{array}{ll}\text { Introduction } & 153\end{array}$

Contractile effects of endocardial damage $\quad 153$

Mechanisms of endocardial influence $\quad 155$

Potential physiological role of endocardium 161

$\begin{array}{ll}\text { Endocardial pathology } & 162\end{array}$

$\begin{array}{ll}\text { Conclusions } & 165\end{array}$

12 Role of lipids and lipid metabolites in myocardial 170 ischaemia M. Spedding and L. Patmore

$\begin{array}{ll}\text { Introduction } & 170\end{array}$

Why are lipids deleterious? 172

Do acyl carnitines have specific effects on calcium 179 mobilization?

Conclusions 
13 Lipid metabolism and myocardial damage during ischaemia T. S. Larsen, T. Myrmel, K. Ytrehus and O. D. Mjøs

Introduction

Endogenous triacylglycerol turnover

Phospholipid degradation

14 Myocardial response to reperfusion after a prolonged period of 201 ischaemia $R$. Ferrari

Introduction $\quad 201$

Experimental models and disease in man $\quad 202$

Detrimental effects of calcium in the ischaemic and reperfused 203 myocardium

Detrimental effects of oxygen in the ischaemic and reperfused 209 myocardium

Detrimental effects of fatty acids and their derivatives in the 213 ischaemic and reperfused myocardium

Conclusion

$15{ }^{31} \mathbf{P}$ and ${ }^{23} \mathrm{Na}$ NMR spectroscopy studies on the calcium

Materials and methods $\quad 224$

Results

Discussion

Conclusion 


\section{The Contributors}

\author{
G. Bullock \\ K-125.10.16 \\ Ciba-Geigy Ltd \\ CH-4002 Basel \\ Switzerland
}

W. T. Clusin

Falk Cardiovascular Research Center

Stanford University School of Medicine

Stanford

CA

USA

\section{W. A. Coetzee}

Ischaemic Heart Disease Research Unit

University of Cape Town Medical School

Observatory 7925

Cape Town

South Africa

\section{R. Coronel}

Dept of Clinical and Experimental Cardiology

Academic Medical Center

Meibergdreef 9

1105 AZ Amsterdam ZO

The Netherlands
V. Darley-Usmar

Biochemical Sciences

Wellcome Research Laboratories

Beckenham

Kent BR3 3BS

UK

\author{
R. Ferrari \\ Cattedra di Cardiologia \\ Universita degli Studi \\ c/o Spedali Civili \\ P le Spedali Civili 1 \\ I-25123 Brescia \\ Italy
}

\section{S. Hein}

Dept of Experimental Cardiology Max-Planck Institute

Benekestr. 2

D-6350 Bad Nauheim

Germany

\section{M. Heinrichs}

Dept of Experimental Cardiology

Max-Planck Institute

Benekestr. 2

D-6350 Bad Nauheim

Germany 


\author{
A. H. Henderson \\ Dept of Cardiology \\ University of Wales College of \\ Medicine \\ Heath Park \\ Cardiff CF4 4XN \\ UK
}

\author{
M. J. Janse \\ Dept of Clinical and Experimental \\ Cardiology \\ Academic Medical Center \\ Meibergdreef 9 \\ 1105 AZ Amsterdam ZO \\ The Netherlands
}

\author{
R. B. Jennings \\ Dept of Pathology \\ Box 3712 \\ Duke University Medical Center \\ Durham \\ NC 27710 \\ USA
}

T. S. Larsen

Dept of Medical Physiology

Institute of Medical Biology

University of Troms $\varnothing$

Troms $\varnothing$

Norway

J. F. Martin

Biochemical Sciences and Cardiovascular Research

Wellcome Research Laboratories

Beckenham

Kent BR3 3BS

UK

O. D. Mjøs

Dept of Medical Physiology

Institute of Medical Biology

University of Troms $\varnothing$

Troms $\varnothing$

Norway
T. Myrmel

Dept of Medical Physiology

Institute of Medical Biology

University of Troms $\varnothing$

Troms $\varnothing$

Norway

\section{H. Opie}

Ischaemic Heart Disease Research Unit

University of Cape Town Medical School

Observatory 7925

Cape Town

South Africa

\section{J. R. Parratt}

Dept of Physiology and Pharmacology

University of Strathclyde

Glasgow G1 1XW

UK

\section{Patmore}

Syntex Research Centre

Research Park

Riccarton

Edinburgh EH14 4AP

UK

\section{P. A. Poole-Wilson}

Dept of Cardiac Medicine

National Heart and Lung Institute

Dovehouse Street

London SW3 6LY

UK

\section{K. A. Reimer}

Dept of Pathology

Box 3712

Duke University Medical Center

Durham

NC 27710

USA 


\author{
T. J. C. Ruigrok \\ Dept of Cardiology \\ Heart Lung Institute \\ University Hospital \\ Heidelberglaan 100 \\ 3584 CX Utrecht \\ The Netherlands

\section{J. Schaper \\ Dept of Experimental Cardiology \\ Max-Planck Institute \\ Benekestr. 2 \\ D-6350 Bad Nauheim \\ Germany}

A. M. Shah

Dept of Cardiology

University of Wales College of Medicine

Heath Park

Cardiff CF4 4XN

UK

\section{Spedding}

Syntex Research Centre

Research Park

Riccarton

Edinburgh EH14 4AP

UK

\section{Stone}

Biochemical Sciences

Wellcome Research Laboratories

Beckenham

Kent BR3 3BS

UK

\section{Szekeres}

Institute of Pharmacology

Albert Szent-Gyorgyi Medical University

Dom Ter 12

H-6701 Szeged

Hungary

C. J. A. Van Echteld

Dept of Cardiology

Heart Lung Institute
University Hospital

Heidelberglaan 100

3584 CX Utrecht

The Netherlands

\section{A. Vegh}

Institute of Pharmacology

Albert Szent-Gyorgyi Medical University

Dom Ter 12

H-6701 Szeged

Hungary

\section{L. Wainwright}

Dept of Physiology and Pharmacology

University of Strathclyde

Glasgow G1 1XW

UK

\section{Weihrauch}

Dept of Experimental Cardiology

Max-Planck Institute

Benekestr. 2

D-6350 Bad Nauheim

Germany

F. M. Williams

Dept of Applied Pharmacology

National Heart and Lung Institute

Dovehouse Street

London SW3 6LY

UK

\section{T. J. Williams}

Dept of Applied Pharmacology

National Heart and Lung Institute

Dovehouse Street

London SW3 6LY

UK

K. Ytrehus

Dept of Medical Physiology

Institute of Medical Biology

University of Troms $\varnothing$

Troms $\varnothing$

Norway 


\section{Winifred Nayler: A Tribute}

We sat, I remember, in that small island of garden around the Marble Arch. Taxis and buses skimmed round us. It was 1970, and the end of the World Congress of Cardiology, at the South Bank, after which there had been a small satellite entitled 'Calcium and the Heart', whose list of contributors now reads like a role of honour. Among them had been Winifred, and we had walked back together.

I was asking her whether she would come over from Australia to give our academic programme at the Institute of Cardiology the scientific boost it urgently needed.

Yes, she said. She would come. But she had some PhD students back in Australia whom she had to see through to the end of their courses. So she would not be free until two years' hence. Was I prepared to wait?

It was, I came to appreciate, characteristic - this care for her studentsand one of the many reasons I am glad I waited. I do not know how many young scientists and doctors passed through her hands during the time she was at the Institute. They came from all over the world and, when I meet them, they all have stories to tell of the fierce and dedicated lady who taught, bullied and cared devotedly for them and who gave them the chance to take part in an exciting world of new thought.

So it is not just unusual scientific achievement, but all those unforgettable stories which have gone to create with affection the inimitable image of the scientist/personality whom this book now honours.

Peter Harris 


\section{Preface}

This book has its origins in a special birthday celebration for Professor Winifred Nayler during the annual meeting of the International Society for Heart Research (European Section) in Glasgow in June, 1990. This celebration took the form of a symposium on acute myocardial injury, an aspect of basic heart research that has attracted the attention of Winifred, and of a number of her friends, for several years. Some of these were present in Glasgow; others who were not, very willingly agreed to contribute to what is, in effect, a Festschrift. The book does not attempt to be comprehensive; it does, however, represent reasonably updated accounts of various facets of the myocardial response to acute injury.

I would like to thank the Bayer Company in Leverkusen, and especially Drs Bohle and Bertschik, for the financial support which made the preparation of this book possible. It is by way of acknowledging and commemorating the work that Winifred Nayler has done in the field of myocardial calcium exchange. Together with her friend Albrecht Fleckenstein, she has contributed more than anyone to our understanding of the mechanism of action and value of calcium antagonists in myocardial ischaemia. On this special occasion of her 60th birthday we salute a fine scientist, a great encourager of younger workers, a tireless advocate for basic cardiovascular research and a good friend and colleague. 